\title{
SOME OBSERVATIONS REGARDING CLERGY AND LAY COMMUNION IN THE ROMANIAN ORTHODOX CHURCH
}

Mihai RĂDUCĂ ${ }^{*}$

\begin{abstract}
Some observations regarding clergy and lay communion in the Romanian Orthodox Church (Câteva observații privind Împărtășirea clerului și a laicilor în Biserica Ortodoxă Română). In the practice of the Romanian Orthodox Church the clergy and lay communion is still a moment within the Divine Liturgy that requests more attention and a proper approach from the ministers and the hierarchy. A limit case encountered is that when on the occasions of large eucharistic synaxes the faithful are not permitted to commune with the Holy Mysteries immediately after the admonition "With fear of God" and are left waitting until the end of the Liturgy. Thus, an eucharistical apartheid is being promoted by the servants. This fact contradicts the aim of the Divine Liturgy pointed out by Saint Nicholas Cabasilas and with the text of the prayers of the Liturgy where the priest asks God to "grant Communion of Your most pure Body and precious Blood to us, and through us to all the people". The lay communion is disseized from the service and placed outside it in order to spear some time for other (optional) liturgical/non-liturgical elements. Moreover, when there are many celebrants, the communion of the clergy often lasts overmuch prolonging the koinonia which is fully captured by the servants. The communion of the priests that are assisting is also an issue. For such and many other liturgical shortcomings some possible solutions are analyzed in the present paper. Liturgical pragmatic solutions and theological foundations could be brought forward from Church Tradition, historical witnesses, contemporary liturgical research and from the current practice of other Orthodox Churches.
\end{abstract}

Keywords: Liturgy, byzantine rite, multiple chalices, Eucharist, synaxis, liturgical reform, clericalization.

PhD Student at Inorganic Chemistry Department, Faculty of Chemistry, University of Bucharest, MA in Theology (University of Bucharest). 


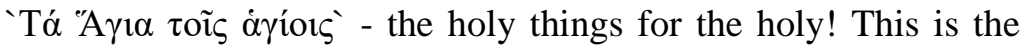
message we hear at each celebration of the Divine Liturgy. It is meant to be the pristine exhortation at once summoning to communion the faithful, and warning off the unworthy ${ }^{1}$, being in the same time an invitation and a warning. Later, for the communion of the faithful a more explicit invitation which is still used today has doubled the original one - "With fear of God, and faith (and love), approach!"2.

Based on the current practice of the Romanian Orthodox Church observed during the last years it seems that an additional indication "should" be said out loud - "With fear of God, and faith, and love, approach! But neither now, nor here... after the service, after we (the servants) shall have departed". This extension could verbalize some situations created on the occasions of large eucharistic synaxes when (sometimes) the lay communion is suppressed from the body of the Liturgy. For such an extirpation the consequence could be easily named as the "excommunication" of the lay from communion within the Divine Liturgy. The reasons and the possible solutions will be analyzed starting from some personal observations.

Such a case has happened on the $26^{\text {th }}$ of October 2017 at the Divine Liturgy celebrated for the Holy and Great Martyr Demetrios of Thessaloniki near ${ }^{3}$ the Patriarchal cathedral in Bucharest, when after the admonition "With fear of God..." one of the many concelebrant bishops, His Grace Timotei Prahoveanul, auxiliary-bishop of the Archdiocese of Bucharest, took the chalice and said to the audience:

„Cei care n-au reușit să se "Those who have not succeeded to împărtășească în această dimineață la commune this morning at the special Liturghia specială, făcută în Liturgy $^{5}$, made in the cathedral, can

${ }^{1}$ Robert F. TAFT, The Precommunion Rites, A History of the Liturgy of St. John Chrysostom, Vol. V (OCA 261), Rome, Pontificio Instituto Orientale, 2000, p. 231.

${ }^{2}$ Robert F. TAFT, The Communion, Thanksgiving, and Concluding Rites, A History of the Liturgy of St. John Chrysostom, Vol. VI (OCA 281), Rome, Pontificio Instituto Orientale, 2008, p. 322.

${ }^{3}$ More precisely the Liturgy was celebrated on a "summer altar" which existence and utility should still be historically, liturgically and canonically argued.

${ }^{5}$ The situation goes so far that there is another Liturgy celebrated earlier in the morning inside the cathedral, with the stated purpose - communion of the faithful, the pilgrims. 
catedrală, pot să se împărtășească îndată după ce vom termina Sfânta Liturghie aici, în ordine în catedrală. Același lucru și mâine dimineață, începând cu orele şase se va săvârşi Sfânta Liturghie în catedrală, unde se vor putea împărtăși toți cei care s-au pregătit pentru aceasta" ${ }^{4}$. receive communion immediately after we finish the Divine Liturgy here, in order in the cathedral. The same tomorrow morning, at 6 o'clock, the Holy Liturgy will be committed in the cathedral, where all those who have prepared will be able receive communion".

Moreover, on the following day, $27^{\text {th }}$ of October 2017, when the Patron of the patriarchal Cathedral, Saint Demetrios Basarabov, is being celebrated the same bishop did the same and said more lapidary: "The faithful, who have permission from their confessor (priest), can commune in the cathedral immediately after the end of the Divine Liturgy". („Credincioșii care au dezlegare de la duhovnicul lor se pot împărtăși în catedrală îndată după terminarea Sfintei Liturghii”’6).

Examples of such kind of situations could continue $^{7}$, but nevertheless it should be observed that this phenomenon is totally in disagreement with the official statement of the Patriarch of the Romanian

See: http://basilica.ro/24-29-octombrie-2017-pelerinajul-la-sarbatoarea-sfantuluicuvios-dimitrie-cel-nou-ocrotitorul-bucurestilor/ (25/03/2018), also: https://basilica.ro/24-29-octombrie-2017-pelerinajul-la-sarbatoarea-sfantului-cuviosdimitrie-cel-nou-ocrotitorul-bucurestilor/ (14/09/2019).

${ }^{4} \mathrm{https}: / / \mathrm{www}$.youtube.com/watch?v=1-rBk8JWbYE, at $2 \mathrm{~h} 2 \mathrm{~min}(14 / 09 / 2019)$.

${ }^{6} \mathrm{https} / / / \mathrm{www}$. youtube.com/watch?v=hFYyjyjng-4 (14/09/2019).

7 For other undesirable de facto excommunications, see: https://www.youtube.com/watch?v=LAg74_28pq4\&t=115s, at $2 \mathrm{~h} \quad 48 \mathrm{~min}$ (30/04/2018); http://basilica.ro/patriarhul-daniel-oficiaza-liturghia-de-hramul-istorical-catedralei-patriarhale-live/ $(21 / 05 / 2018)$ https://www.facebook.com/trinitastv/videos/866007560250575/, at $2 \mathrm{~h} \quad 14 \mathrm{~min}$ (21/01/2018); http://basilica.ro/mitropolitul-iosif-naniescu-si-mosul-hgheorghe-lazarau-fost-proclamati-sfinti/ (25/03/2018); https://www.youtube.com/watch?v=S49I8JJv8yQ $\quad 2 h \quad 58 \quad \min \quad(30 / 04 / 2018)$; https://www.youtube.com/watch?v=S49I8JJv8yQ (25.03.2018); http://basilica.ro/buna-vestire-la-catedrala-din-iasi-patriarhul-romaniei-a-oficiatsfanta-liturghie-impreuna-cu-14-ierarhi-video/ $(25 / 03 / 2018)$; https://www.youtube.com/watch?v=PMEq10uABWs, at 2h $18 \mathrm{~min}(16 / 08 / 2018)$; https://www.youtube.com/watch?v=otVF3id2cwg\&t=8261s, at $2 \mathrm{~h} \quad 17 \mathrm{~min}$ (02/11/2018); https://www.youtube.com/watch?v=xLocuqEorQ4, at $2 \mathrm{~h} 45 \mathrm{~min}$ (02/11/2018). 
Orthodox Church. His Beatitude Daniel, in an interview given at his $10^{\text {th }}$ patriarchal anniversary, speaking about the practical necessity of the construction of the National Cathedral declared:

"I have also said it as a joke that we must not practice a liturgical apartheid, the clergy in the church and the people out..."

The Patriarch is properly claiming the necessity of spacious ecclesiastical edifice suitable with the current need. I agree that during the service is not ideal that manifold clergy to occupy almost the whole building and the overwhelming majority of the faithful to stay outside it facing the vicissitudes of the weather ${ }^{9}$. Based on a compassion spirit with the flock this may be one of the explanations why more and more Divine Liturgies are celebrated outside the $\operatorname{church}^{10}$, on stages $^{11}$, by some

8 The original text: „Am şi spus în glumă că nu trebuie să practicăm un apartheid liturgic, clerul în biserică şi poporul afară...", available online: http://basilica.ro/interviuslujirea-bisericii-jertfelnicie-si-bucurie/ (22/09/2019), http://basilica.ro/interviuinedit-patriarhul-daniel-vorbeste-despre-misiunea-bisericii-in-ultimii-10-ani/ (22/09/2019).

${ }^{9}$ For example, see the Divine Liturgy celebrated on the Great Thursday on $25^{\text {th }}$ of April 2019 in the current Patriarchal Cathedral when the church was full of bishops and concelebrants gathered for the Service of Holy and Great Myrrh.

${ }^{10}$ It is worth noting a double standard applied here. Based on a decision of the Romanian Holy Synod the Marriage and Baptism services are banned to be celebrated elsewhere than in the church, there is no such decision regarding Divine Liturgy, see: Decision of The Holy Synod no. 311 from 28/02/2013, http://patriarhia.ro/hotararea-nr-311-din28-02-2013-a-sfantului-sinod-al-bisericii-ortodoxe-romane-2857.html. (30/09/2019). The Orthodox catechism for the question "Where is the Divine Liturgy celebrated?" gives the following answer "Only in the church or in chapels and chapels sanctified with Antimension, in the holiest part, that is, in the Holy Altar. Only in exceptional cases, such as on the battlefield, it is celebrated only with the permission of the local bishop. Outside the Church the Divine Liturgy can be celebrated in a house or in a clean place, on a table on which the Holy Antimension is situated. Without it, there can be no Divine Liturgy in the Church, where it always sits on the Holy table, nor outside the church" (own translation). See: Învățătură de credință creștină Ortodoxă, București, Edit. Institutului Biblic și de Misiune Ortodoxă, 2015, p. 301, see also Catehismul creștinului dreptcredincios, București, Edit. Basilica, 2019, p. 86. „Exceptional cases” still represents an ambiguous expression that should be clarified in the future.

11 Unfortunately doing so, they do not only convert or reduce the Divine Liturgy into a concert „on stage”, but they find the opportunity to bring innovations into the church rite, 
members of the Romanian Holy Synod. The reality is that, if they do not promote, at least they allow tacitly the implementation and proliferation of an eucharistical apartheid, the clergy receiving communion during the Liturgy while the lay after the end of the service ${ }^{12}$.

Neglecting the lay communion from its genuine place which could be then the purpose of the Divine Liturgy? Saint Nicholas Cabasilas in this respect write that:

"The opera/ work of the Holy celebration of the Holy Mysteries is the change of the gifts into the Divine Body and Blood; The purpose/the finality is the sanctification of the faithful, who through them receive the forgiveness of sins, the inheritance of the Kingdom of heaven and the other like them"13.

Each priest or bishop serving the byzantine rite prays and confess before the exclamation ,the holy things for the holy":

"Hearken, O Lord Jesus Christ our God, from Your holy dwelling place and from the throne of glory of Your Kingdom, and come to sanctify us, You Who are enthroned with the Father on high and are present among us invisibly here. And with Your mighty hand, grant Communion of Your most pure Body and precious Blood to us, and through us to all the people"14.

they operate a liturgical reform by adopting allogenic practices. For example, nowadays more and more Romanian bishops are celebrating the Divine Liturgy versus populum as an influence of the roman-catholic post Second Vatican Council practice or even driven, why not, by the visual requirements of an online broadcasted event [on this issue see Mihail Khalid QARAMAH, "Unitate și «reformă liturgică» în Biserica Ortodoxă Română”, in Studia Theologica Orthodoxa Doctoralia Napocensia, 2/2019, p. 241-242 and more extended: Mihail QARAMAH, "Este uniformitatea un imperative al unitătii liturgice?", in Florin Dobrei (ed.), Credință - Unitate - Națiune : simpozion teologic internațional, Deva, 19-20 octombrie 2018, Stockholm, Felicitas Publishing House/Deva, Edit. Episcopiei Devei şi Hunedoarei, 2018, p. 547-550]. For the history and the repercussions of the celebratio versus populum, see Uwe Michael LANG, Turning Towards the Lord: Orientation in Liturgical Prayer, San Francisco, Edit. Ignatius, 2004.

${ }^{12}$ See also: M. K. QARAMAH, "Unitate și «reformă liturgică»...", p. 242-243.

${ }^{13}$ See: Nicolae CABASILA, Explicări la dumnezeiasca Liturghie, Sibiu, Edit. Deisis, 2014, p. 337-338 (our translation).

${ }^{14}$ See: Liturghier, București, Edit. Institutului Biblic și de Misiune Ortodoxă, 2012, p. 185 (our translation). 
The normative place for receiving communion is within the Divine Liturgy and, according to the evidences mentioned above, the servants have the duty to do what they confess - to offer Christ to those who are prepared and wish to commune. Instead, they promote an eucharistical clericalization. In this way they are not servents of the Divine Mysteries, but rather those who are sequestering Them. Romanian orthodox faithful prove to be very lenient with their shepherds and receive with humble this discriminatory attitude of the clergy, although the Status of Organization And Functioning Of The Romanian Orthodox Church, at article 45, states that:

"The faithful of the parish have the following rights: To receive religious assistance, to elect and to be elected in the parish bodies, to benefit from philanthropic aid, according to possibilities; and duties: to sustain, strengthen and confess the faith of the Orthodox Church; to live according to the teachings of Orthodox faith; to participate to the holy services; to commune with the Holy Mysteries; to fulfill the deeds of christian mercy; to support and help the church and its servants"15.

Another issue is that not only the Romanian faithful do not receive the communion during the service, but they are patient observers of allogenic elements which fracture the fluency of the Liturgy, such as the commemoration of the living with polychronia, award festivities, fraternal messages from invited guests. Placing those elements after the communion of the servants provokes an artificial hiatus ${ }^{16}$. Moreover, when the number of servants is high the koinonia could last up to 40-50 minutes because Romanian communion rubrics ${ }^{17}$ prescribe a synchronous

${ }^{15}$ See: Statutul pentru organizarea și funcționarea Bisericii Ortodoxe Române, București, Edit. Institutului Biblic și de Misiune al Bisericii Ortodoxe Române, 2008, p. 37 (our translation).

16 Perhaps today the moment of koinonia is not perceived as one single part due to the insertion of the admonition and communion prayers which were not present in the Liturgy from the beginning, but by default both parts of the same unit, the clergy and faithful communion, should be possible. A possible contribution may be the change of perception about whether the communion is received or taken by the celebrant. For this topic, see: Robert F. TAFT, Beyond East and West, Problems in Liturgical Understanding, Rome, Pontifical Oriental Institute, 1997, p. 133-142, and also: R. F. TAFT, The Communion..., p. 84-95.

17 See: Liturghier, București, Edit. Institutului Biblic şi de Misiune Ortodoxă, 2012, p. 187-194. 
way of communicating with the Holy Mysteries which is very good in case of few celebrants, but it becomes impracticable for a service with many bishops, priests and deacons.

Without considering the number of celebrants and without major variation, the clergy communion takes place as such: the protos fractions the Agnus and distributes the Holy Body to every concelebrant. Nobody consume the Bread until the last piece is taken by the protos, which means that some of the ministers must keep the Holy Body in their hands for many minutes. After that, the three prayers for the communion are said. All consume the Body simultaneously. In the case partaking of the Blood they must come one by one at the chalice ${ }^{18}$.

To overcome the prolonging of the clergy communion moment, instead of one chalice several could be consecrated during the Anaphora. Hence there is enough time to share the communion in the same time to the many ministers and immediately after to several rows of faithful. The celebration of the Divine Liturgy with multiple chalices and even patens represents the suitable historical solution for managing the time of the Communion Rite. There are multiple evidence for such a practice ${ }^{19}$, one of them, a $12^{\text {th }}$ century letter from a patriarch of Constantinople to the bishop Paul of Gallipoli, underlines the state of affairs encountered in that context. Prescribing some liturgical guidelines regarding the rite of the Prothesis, the Patriarch writes:

But even if, as often happens, there are many [vessels] because of the large number of communicants, the diskoi and the divine chalices are still placed on the same prothesis table, but crosswise - i.e., the diskoi in the form of cross, with the divine chalices in the angles. And when they are brought to the holy altar [at the Great Entrance], they are arranged there according to the same schema ${ }^{20}$.

${ }^{18}$ See the appendix for a solution.

${ }^{19}$ An important part of these evidence is gathered and analyzed by Taft in R. F. TAFT, The Communion..., p. 250 , especially note 203 . This practice was also the subject of my master thesis. For a polemical article on this topic, see: Mihai RĂDUCĂ, „Slujirea Dumnezeieștii Liturghii cu mai multe potire: samavolnicie liturgică sau necesitate practică fundamentată istoric? Răspuns la o teologumenă", in Ortodoxia, 1/2019, p. 66-82.

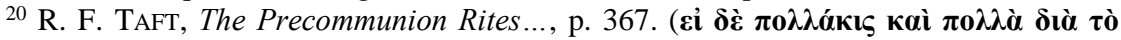

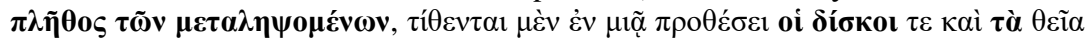


The key words that must be highlighted are "as often happens, there are many [vessels] because of the large number of communicants". So, it is normal to suit the number of vessels according to the number of communicants.

Furhermore, it is a lack of respect from the clergy towards the faithful that immediately after the communion of the clergy, the celebrants begin to eat the antidoron or prosphora, to drink water and wine and to start a chatting session converting the koinonia moment into a "kerasma" during which the faithful are still waiting that one of them to withdraw from the relaxation moment and to call them to partake. This moment of relaxation could take place during the communion of the faithful.

Also, it should be noticed that, especially when there are many priests who attend the Divine Liturgy, but they do not celebrate, they neither commune although according to the $8^{\text {th }}$ Apostolic Canon they must commune with the Body and the Blood of Christ. Unfortunately, it can be understood that these assisting priests are present there rather to be liturgical furniture or design elements for a broadcasted show.

Another aspect regards the attitude cultivated among the faithful with respect to receiving communion. A discipline regarding the communion must be cultivated among the faithful. There are churches where the Holy Mysteries are delivered on demand, whenever there is a demand during the Divine Liturgy. This fast-food-like type of communion disarranges the liturgical flow and should be abolished from my perspective. Generally speaking, such practices that are not in the Tradition of Orthodoxy could be avoided through the liturgical education of the future priests during the years of spent in theological schools. The lack of theological education is both the cause of the current situation from the Romanian Orthodox Church.

To conclude, most of the communion related problems that Romanian faithful and clergy alike encounter nowadays have a long-term solution which is the proper liturgical and theological education of the future priests and the proper catechization of the people. To overcome the eucharistical apartheid phenomenon, the celebration of the Divine

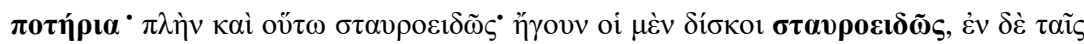

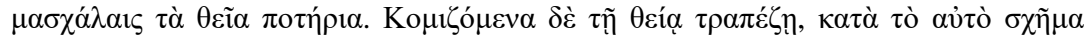

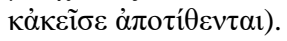


Liturgy with multiple patens and chalices must be adopted whenever is required. For a smooth implementation the ministers must be officially aware of this practice and, even more, the personal example of the local bishop is a strong driving force. Certainly now is the time for the Holy Synod of the Romanian Orthodox Church to start discussing these problems, also taking into account the arguments of the liturgists and thus to search for real solutions.

\section{References:}

1. Catehismul creștinului dreptcredincios, București, Edit. Basilica, 2019;

2. Învățătură de credință creștină Ortodoxă, București, Edit. Institutului Biblic și de Misiune Ortodoxă, 2015;

3. Liturghier, București, Edit. Institutului Biblic și de Misiune Ortodoxă, 2012;

4. Statutul pentru organizarea şi funcționarea Bisericii Ortodoxe Române, București, Edit. Institutului Biblic și de Misiune al Bisericii Ortodoxe Române, 2008;

5. CABASILA, Nicolae, Explicări la dumnezeiasca Liturghie, Sibiu, Edit. Deisis, 2014;

6. LANG, Uwe Michael, Turning Towards the Lord: Orientation in Liturgical Prayer, San Francisco, Edit. Ignatius, 2004;

7. TAFT, Robert F., Beyond East and West. Problems in Liturgical Understanding, Rome, Pontifical Oriental Institute, 1997;

8. TAFT, Robert F., The Communion, Thanksgiving, and Concluding Rites, A History of the Liturgy of St. John Chrysostom, Vol. VI (OCA 281), Rome, Pontificio Instituto Orientale, 2008;

9. TAFT, Robert F., The Precommunion Rites, A History of the Liturgy of St. John Chrysostom, Vol. V (OCA 261), Rome, Pontificio Instituto Orientale, 2000;

10. QARAMAH, Mihail, "Este uniformitatea un imperative al unităţii liturgice?”, in Florin DOBREI (ed.), Credință - Unitate - Națiune : simpozion teologic internațional, Deva, 19-20 octombrie 2018, Stockholm, Felicitas Publishing House/Deva, Edit. Episcopiei Devei şi Hunedoarei, 2018, p. 537-558;

11. QARAMAH, Mihail Khalid, "Unitate și «reformă liturgică» în Biserica Ortodoxă Română", in Studia Theologica Orthodoxa Doctoralia Napocensia, 2/2019, p. 228-245. 


\section{Appendix}

One diataxis that should be brought into attention as an example of how to manage the communion within the Divine Liturgy belongs to Demetrios Gemistos $\left(14^{\text {th }} \mathrm{c}\right.$.). The translated text is resumed below:

The patriarch, or the protopope at his binding, divides the rest of the particles into small pieces sufficient for everyone. Then the [newly] ordained bishop approaches, or the first among them if there is no [episcopal] ordination, and taking a particle of the holy bread, he gives it to the patriarch. He [the patriarch], taking it in the right hand and holding it in the palm with three fingers lest any of it fall. And he kisses the patriarch's hand and cheek, while the patriarch says: „Christ is in our midst,” and the bishop [replies]: „He is and shall be!”

And both of them, bowing before the holy altar, pray to themselves, saying: „At Your Mystical Supper,” and „I believe O lord and confess...” And lastly, ,May it not be for me unto judgement or condemnation...”

Holding their hands over the holy altar, each one receives what is in his hand with fear and all care. Then they wipe their hands with the eiliton. The bishop taking the first chalice, gives it to the patriarch who holds a veil over his beard and breast. Then the patriarch, taking the chalice with the veil in both hands, partakes of it three times. And after this, having wiped his lips and the sacred chalice with the veil in his hand, and kissing the outer lip of the chalice, he [the patriarch] takes the chalice himself, and giving the veil to the bishop, he [the bishop] communicates then, doing the same [as the patriarch did].

And thus the bishop, taking the chalice with the veil, with some of the deacons helping him lest he stumble, stands by the right pillar [of the altar ciborium] giving communion to all who come up to receive. The patriarch, taking the holy diskos, gives particles of the holy bread to the rest of the bishops and presbyters, and each of them does as was said above. Then they receive from the holy chalice [being held by the first bishop].

The first bishop to communicate from among the rest of the bishops is given the second chalice by the deacons, and he stands by the left column, and with him stand those holding the rest of the chalice.

The deacons go off first to place of the bema, and after asking and receiving forgiveness of one another, tie up their oraria and also approach and receive the holy bread and chalice ${ }^{21}$.

${ }^{21}$ R. F. TAFT, The Communion..., p. 100-101. 